\title{
Sediment flux in a rip channel on a barred intermediate beach under low wave energy
}

\author{
B. Greenwood ${ }^{1}$, R. W. Brander ${ }^{2}$, E. Joseph ${ }^{2}$, M. G. Hughes ${ }^{3}$, \\ T. E. Baldock ${ }^{4} \&$ T. Aagaard ${ }^{5}$ \\ ${ }^{1}$ Department of Physical \& Environmental Sciences, \\ University of Toronto Scarborough, Canada \\ ${ }^{2}$ School of Biological, Earth \& Environmental Sciences, \\ University of New South Wales, Australia \\ ${ }^{3}$ Geoscience Australia, Marine and Coastal Environment Group, \\ Australia \\ ${ }^{4}$ Department of Civil Engineering, University of Queensland, Australia \\ ${ }^{5}$ Institute of Geography \& Geology, University of Copenhagen, Denmark
}

\begin{abstract}
The classic model of water and sediment flux in barred surf zones is a net flux landward across a nearshore bar, alongshore in a feeder channel, and offshore in narrow jet-like flows in a rip neck cut through the bar; this circulation is frequently modulated by the tide, even under micro-tidal conditions. Water levels, waves, currents and suspended sediment transport (SST) were recorded at elevations of $\mathrm{z}=0.13,0.26$ and $0.39 \mathrm{~m}$ in a rip neck on an intermediate bar-rip beach at a micro-tidal site, Bennett's Beach, NSW, Australia. Measurements revealed SST was driven by quasi-steady rip currents and by gravity and infragravity waves. The balance between these components determined the magnitude and direction of the overall net SST. Tentative conclusions are that:

(i) the direction of the overall net SST rate in the rip neck was dominated, as expected, by offshore-directed mean cross-shore currents, especially around high tide; at this time the SST rates due to gravity and infragravity waves were relatively small and somewhat variable in direction.

(ii) as the tide fell, relatively large SST rates were directed onshore by shoaling gravity waves propagating through the neck, which opposed and even exceeded the rip current transport. At mid-tide, the transport by infragravity waves complemented the gravity waves such that the overall net flux of
\end{abstract}


suspended sediment was directed onshore into the rip cell at the two lowest elevations.

(iii) whenever the SST by the rip current and by shoaling waves was close to a balance, it was the infragravity waves that controlled the rate and direction of the overall net suspended sediment flux.

Keywords: rip currents, sediment flux, wave and tide modulation.

\section{Introduction}

Rip currents are an integral component of the cellular water and sediment circulation in surf zones, both marine and lacustrine. On barred coasts, rips are directed offshore as jet-like flows in constricted channels cut through the bar, and often fed by longshore-directed feeder currents. The classic circulation model is a net flux of water landward across the bar followed by a longshore and seaward flux through the feeder channel and rip neck (Komar [1]). This flux is often modulated by the tide, even under micro-tidal conditions (Aagaard et al. [2]; Brander [3, 4]; MacMahan et al. [5, 6]). Rip currents may play an important role in maintaining the nearshore sediment balance, although this is far from proven, since measurements are limited. In this paper, the flux of suspended sediment in a rip channel neck under breaking swell and wind waves is documented, and the role of currents, waves at a range of frequencies, and the tide is assessed.

\section{Location and methods}

Mean water levels, waves, horizontal currents, and suspended sediment concentrations were recorded in a rip neck at Bennett's Beach, NSW, Australia (Figs 1, 2 and 3) in February, 2004. The beach is micro-tidal, with a mixed semidiurnal regime, and was in an "intermediate bar-rip" state (Wright and Short [7]) during the measurement period. The beach consists of medium sand, and samples from the bar were well-sorted, but bimodal, with a mean grain size of $1.79 \varnothing(300 \mu \mathrm{m})$, a standard deviation of $0.37 \varnothing(91 \mu \mathrm{m})$ and a negative skewness, -0.61 凤, typical of wave-winnowed sand (Greenwood and DavidsonArnott [8]). The beach was subject to long period swell from the SE during the experiment, coupled with a variable wind-wave field forced by a sea breeze. The beach is oriented to a SSE exposure, with fetch restricted to the north by the Little Gibber headland (Dark Point) and Broughton Island, and to the south by Yacaaba Head, and Cabbage Tree and Boondelbah Islands. The study rip cell was asymmetric with a dominant feeder current flowing from the southwest. Figure 2 illustrates the rip cell on Feb. $19^{\text {th }}$ with tracer injected at the head of the feeder channel; the narrow rip neck and diffused rip head are shown. The nearshore bathymetry (Fig. 3) consisted of a dominant, oblique nearshore bar welded to a shoal to the south and extending alongshore in a north-easterly direction to end at the rip neck; a trough separated the bar from the beach face, varying in depth from near zero where the bar was welded to the shoal, to $\sim 1 \mathrm{~m}$ deep before it turned offshore into the rip neck, which at high tide was $\sim 1.75 \mathrm{~m}$ 
deep. Over the three-day monitoring period, the transverse bar moved both northeastwards and offshore forcing the rip neck to migrate slightly northward also, but causing a distinct constriction and increase in depth of the channel (Figure 3).

The study cell was instrumented with sensors deployed each day at high tide in the centre of the rip neck (P1, Fig. 3) to measure: (a) cross-shore and alongshore (relative to the average local shoreline orientation) horizontal currents, at elevations of $\mathrm{z}=0.13,0.39,0.50 \mathrm{~m}$, using biaxial electromagnetic urrent meters (Marsh-McBirney, OEM 512); (b) sediment concentrations at $\mathrm{z}=0.13,0.26,0.39 \mathrm{~m}$, using optical backscatter sensors (D\&A Instruments, OBS-1P and OBS-3); and (c) mean water surface elevation and waves, using a strain-gauge pressure sensor (Druck-1830). Waves incident to the surf zone were recorded by a pressure sensor deployed $\sim 130 \mathrm{~m}$ directly offshore of the bar (P3). Data were recorded continuously at $4 \mathrm{~Hz}$, and stored in consecutive $\sim 17$-minute "bursts". Records were taken during falling spring tides from high water to low water and back to mid-tide.

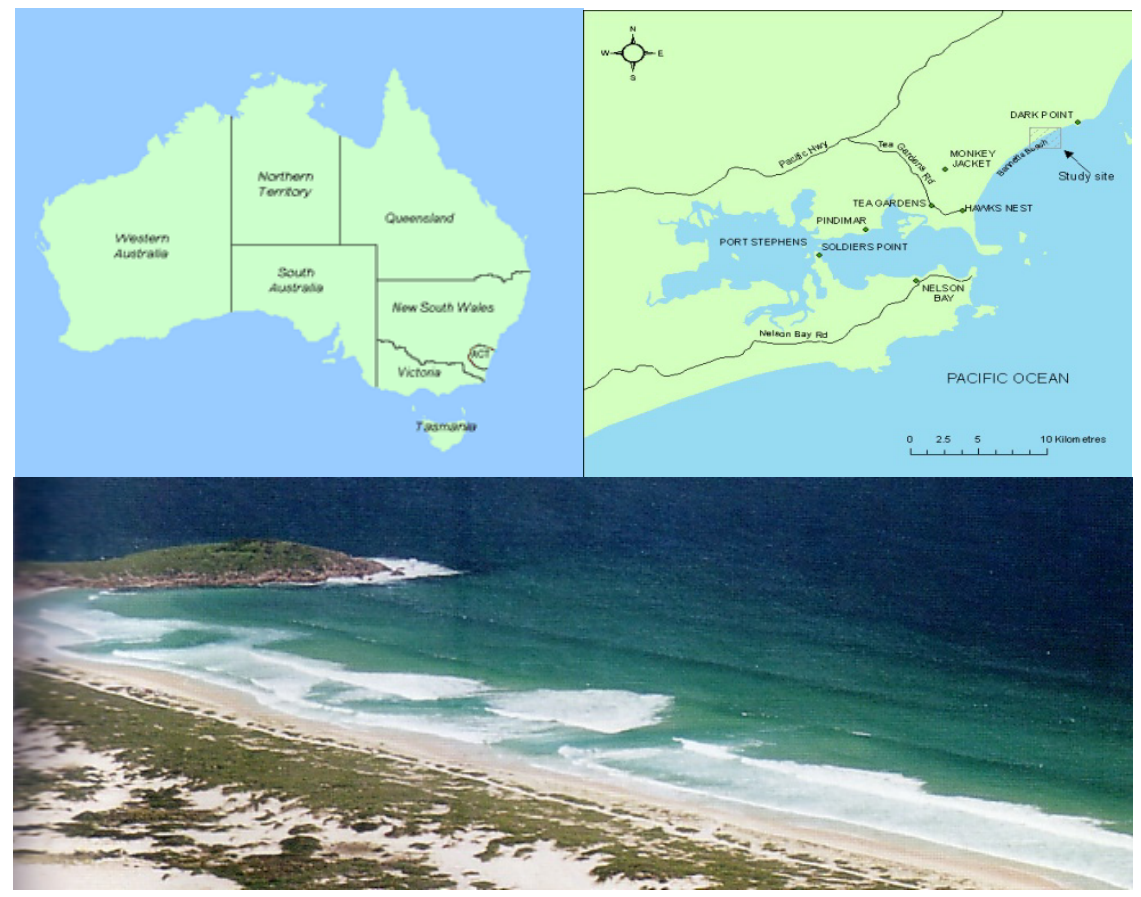

Figure 1: Bennett's Beach, NSW, Australia; the arrow (upper right panel) marks the study site. Also shown is an oblique aerial view of the study site. Note: the shoals, nearshore bars and the rip cells are not identical to those during the study period on this intermediate barrip beach. 


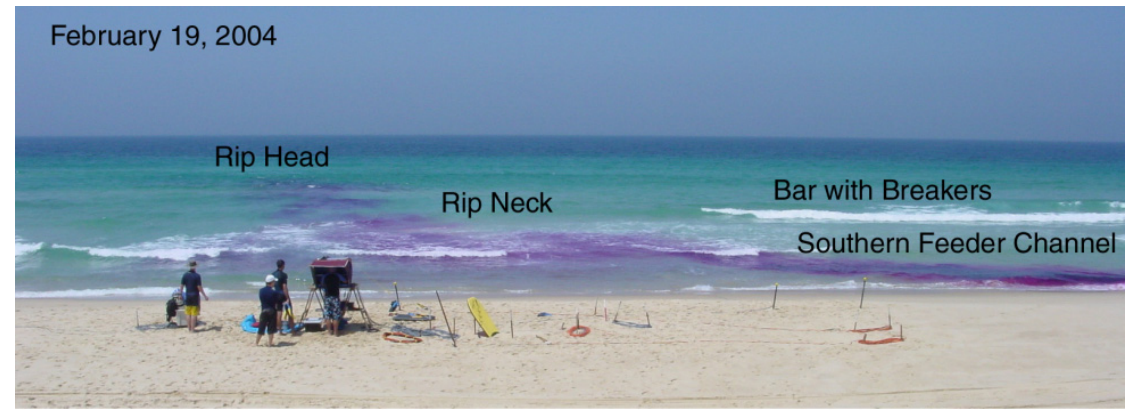

Figure 2: $\quad$ Study rip cell at Bennett's Beach with tracer, Feb. 19 $9^{\text {th }}, 2004$. Note the breaking waves on the bar, the feeder current, the rip neck and the rip head.
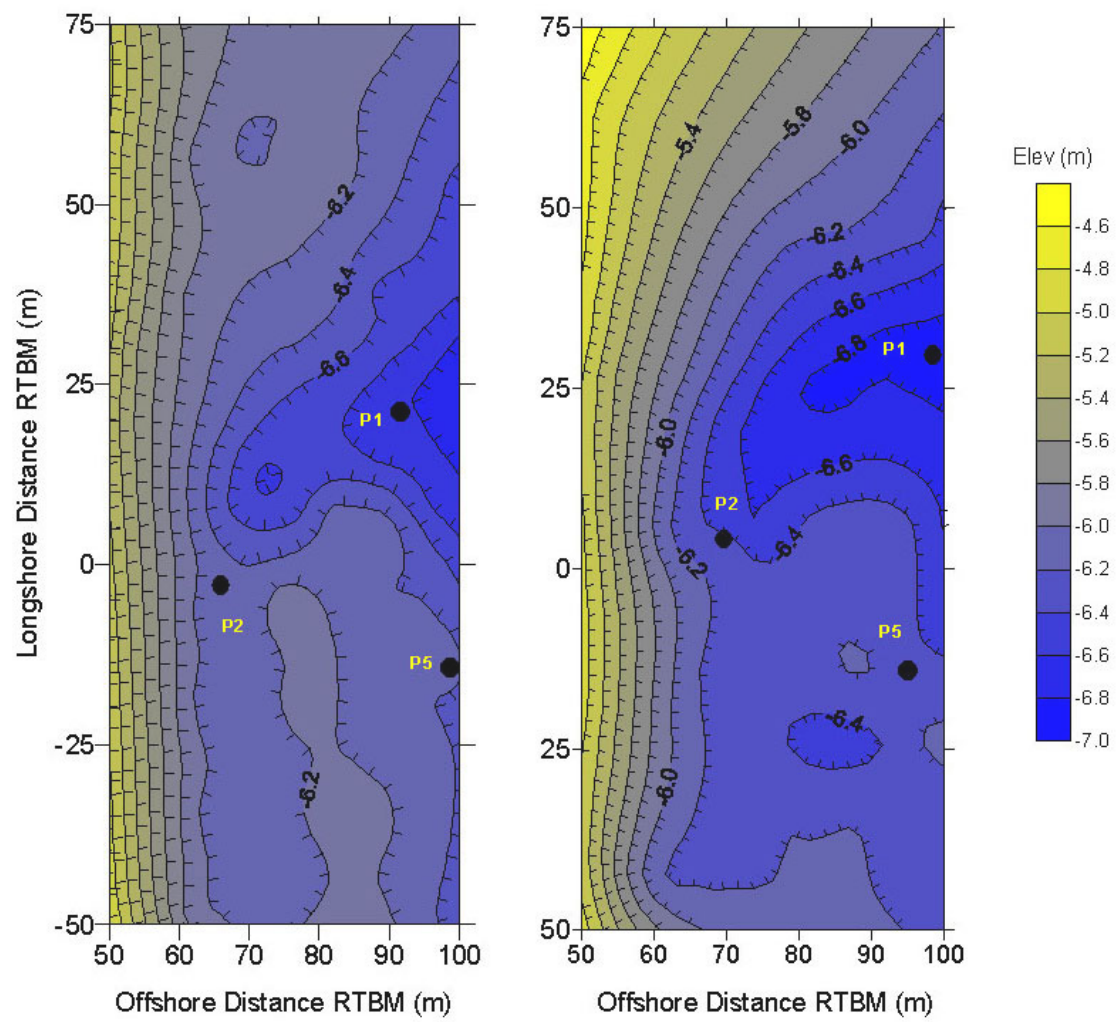

Figure 3: Nearshore bathymetry, Bennett's Beach, Feb. $19^{\text {th }}$ (left panel) and Feb. $21^{\text {st }}$ (right panel). P1 marks the location of the instrument pod in the rip neck and P2 and P5 locates the pods in the feeder channel and on the bar crest. Pods were relocated each day as the morphology changed. Note: RBTM is relative to the bench mark. 
Time series of instantaneous horizontal fluid velocities and suspended sediment concentrations were used to compute the SST rates for each "burst". Concentrations measured at 0.13 and $0.26 \mathrm{~m}$ were coupled with velocities measured at $0.13 \mathrm{~m}$; concentrations measured at $\mathrm{z}=0.39 \mathrm{~m}$ were coupled with velocities measured $\mathrm{z}=0.39 \mathrm{~m}$. There is potential error here (see Austin and Masselink [9]); however, in all cases the measured currents at $0.13 \mathrm{~m}$ were only very slightly different from those measured at 0.39 and $0.50 \mathrm{~m}$; the latter two were essentially identical. The sensors were supported on a solid heavy base, which did not allow significant shifts in elevation once the support settled, and in any case the transports were averaged over 17-minute blocks.

Time series of "collocated" velocities and concentrations were used to compute the time-averaged net, $\left\langle q_{s}\right\rangle_{\text {net }}$, mean, $\left\langle q_{s}\right\rangle_{\text {mean }}$ and oscillatory $\left\langle q_{s}\right\rangle_{\text {osc }}$ components of the SST rate at each elevation (see Jaffe et al. [10]; Osborne and Greenwood [11]):

$$
\begin{aligned}
& <q_{s}>_{\text {net }}=\frac{1}{T} \int_{0}^{T} \int_{0}^{h} U_{(z, t)} C_{(z, t)} d z d t \\
& <q_{s}>_{\text {mean }}=\frac{1}{T}\left[\int_{0}^{T} \int_{0}^{h} U_{(z, t)} d z d t\right] * \frac{1}{T}\left[\int_{0}^{T} \int_{0}^{h} C_{(z, t)} d z d t\right] \\
& <q_{s}>_{\text {osc }}=\frac{\Delta f}{F} \int_{0}^{T} \int_{0}^{h} C_{U C(f)} d z d t
\end{aligned}
$$

where $U=$ instantaneous velocity, which can be disaggregated into cross-shore and alongshore components; $\mathrm{C}=$ instantaneous sediment concentration; $z=$ elevation; $t=$ time; $C_{U C(f)}=$ cospectrum of $\mathrm{U}$ and $\mathrm{C} ; \Delta f=$ unit bandwidth; $F=$ frequency range; $h=$ water depth; and $T=$ time. The cospectrum identifies SST due to oscillatory motions at different frequencies (Huntley and Hanes [12]; Davidson et al. [13]); gravity and infragravity waves were separated at 0.04 or $0.05 \mathrm{~Hz}$, at pronounced reductions in variance at these values on each day.

\section{Results: February 19th and 21st, 2004}

\subsection{Water levels}

The range in water levels recorded in the rip neck (P1) were larger than the tidal range recorded offshore at $\mathrm{P} 3$; there was also a slight shift in the timing of the low water recorded in the rip neck again relative to the tide offshore (Fig. 4). The maximum water level range recorded over the measurement period offshore at P3 was $0.49 \mathrm{~m}$ on both Feb. $19^{\text {th }}$ and $21^{\text {st }}$; in contrast, in the rip neck the average range in water level for the two days was $0.61 \mathrm{~m}$, an amplification of $\sim 30 \%$. 

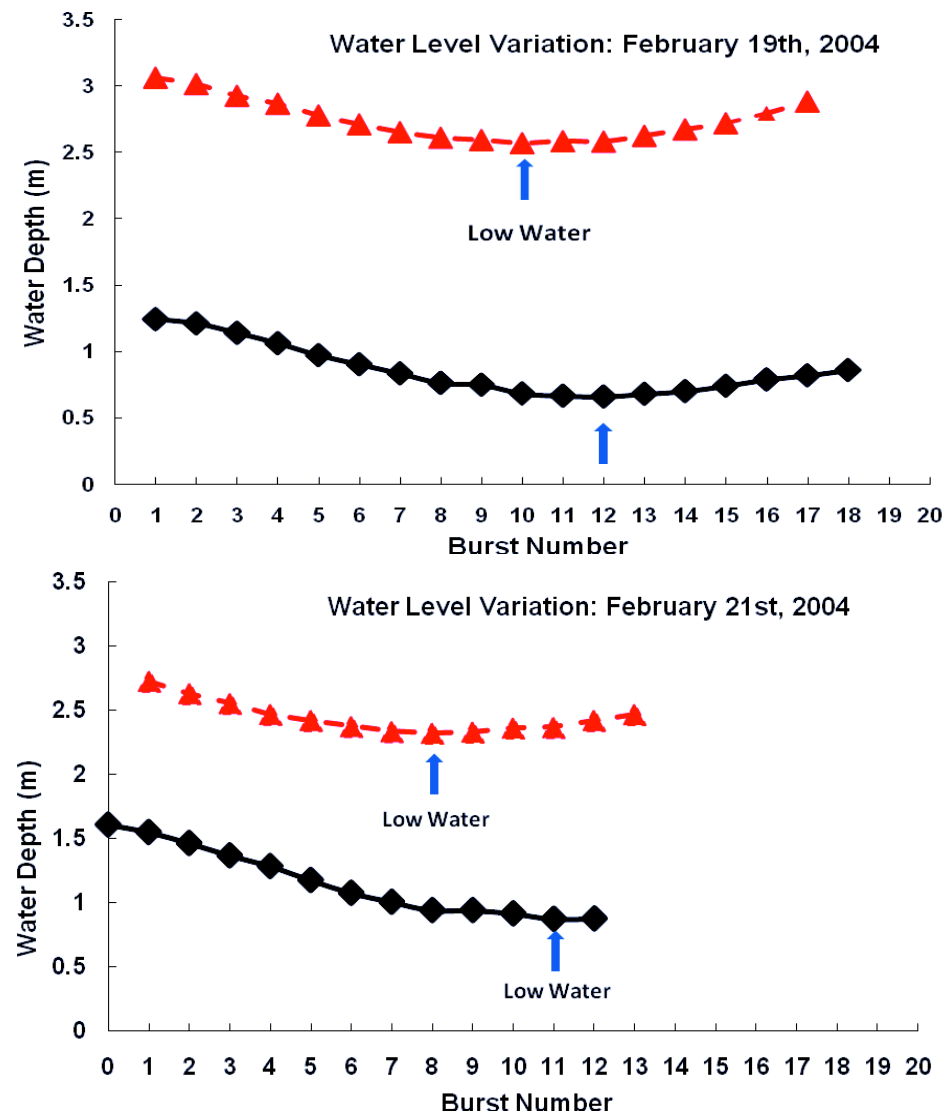

Figure 4: Water levels outside the surf zone at P3 (triangles) and in the rip neck at P1 (diamonds). Note the small differences in amplitude and phase between the two measurement locations.

\subsection{Waves}

The primary energy source driving rip circulation on both days was an incident gravity wave field consisting of both long period swell $(0.100-0.065 \mathrm{~Hz} ; 10-16 \mathrm{~s})$ and locally generated wind waves $\left(0.17-0.12 \mathrm{~Hz} ; 6-8 \mathrm{~s}\right.$; Fig. 5). Feb. $21^{\text {st }}$ was more energetic than the $19^{\text {th }}$, but spectra on both days were dominated by narrow banded, long-crested swell. Wind waves grew in the afternoons with the seabreeze, broadening the incident spectra (Fig 5). Outside the surf zone, little energy was recorded at infragravity frequencies, although significant peaks at $0.013 \mathrm{~Hz}(73 \mathrm{~s})$ and $0.010 \mathrm{~Hz}(100 \mathrm{~s})$ occurred late in the tidal cycle on the $21^{\text {st }}$ (Rip 21_4 and Rip 21_11; see Fig. 5). There was a reduction in the overall variance at incident frequencies in the rip neck (P1) compared to offshore, as well as a significant "red shift" in the current spectra, with distinct peaks at infragravity frequencies, $0.015-0.019 \mathrm{~Hz}(53-67 \mathrm{~s}$; Fig. 6). 

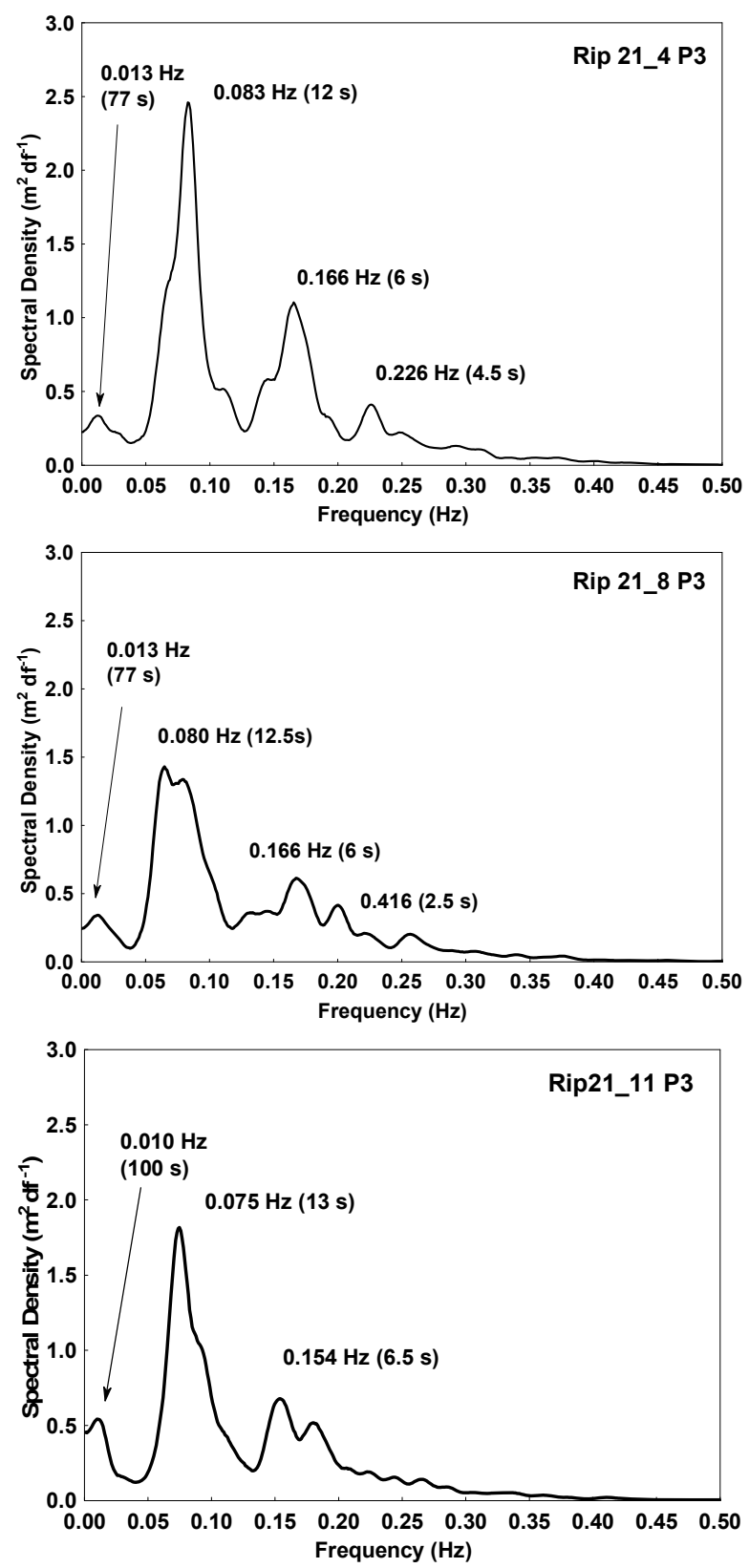

Figure 5: Wave spectra recorded offshore at P3 from mid tide (Rip 21_4; 1458 h) to low tide (Rip 21_11; 1658 h) on Feb. 21 $1^{\text {st }}, 2004$. 

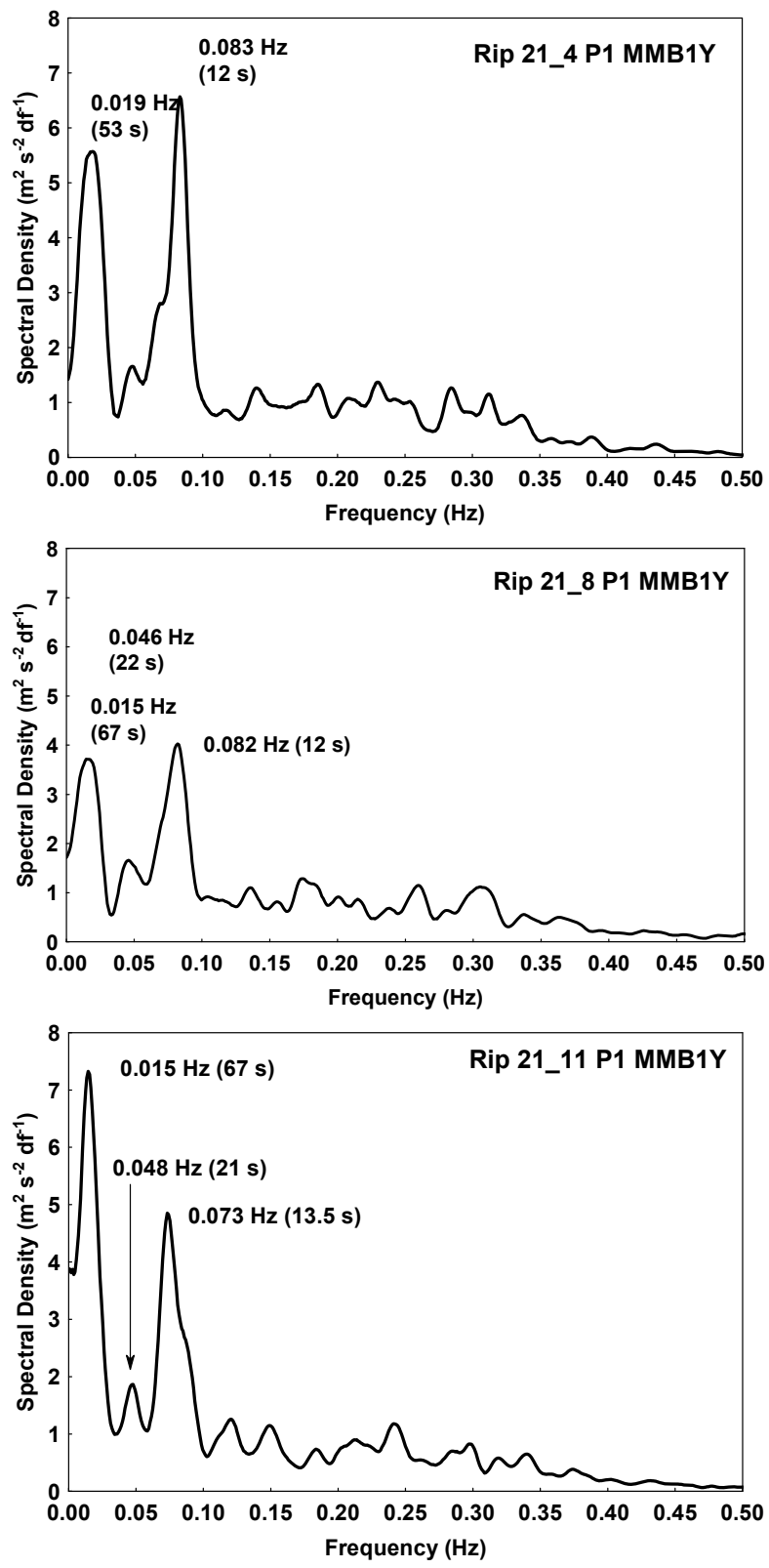

Figure 6: Cross-shore current spectra recorded in the rip neck from mid tide (Rip 21_4; 1458 h) to low tide (Rip 21_11; 1658 h) on Feb. 21 ${ }^{\text {st }}$, 2004. 


\subsection{Mean current speed in the rip neck and tidal levels}

Rip current speeds have been shown to increase as the tide falls under both low and high energy conditions, as a result of increased wave breaking and also topographic forcing as the cross-sectional area of a rip channel is reduced by falling water levels in barred systems (e.g. Aagaard et al. [2]; Brander [3]; Brander [4]; MacMahan et al. [5]). Fig. 7 illustrates the relationship between water level in the rip neck and the magnitude of the mean cross-shore current during the falling stage of the tide at Bennett's Beach. A positive relationship existed between rip current speed and water level (see also Castelle and Bonneton [14], Castelle et al. [15]).
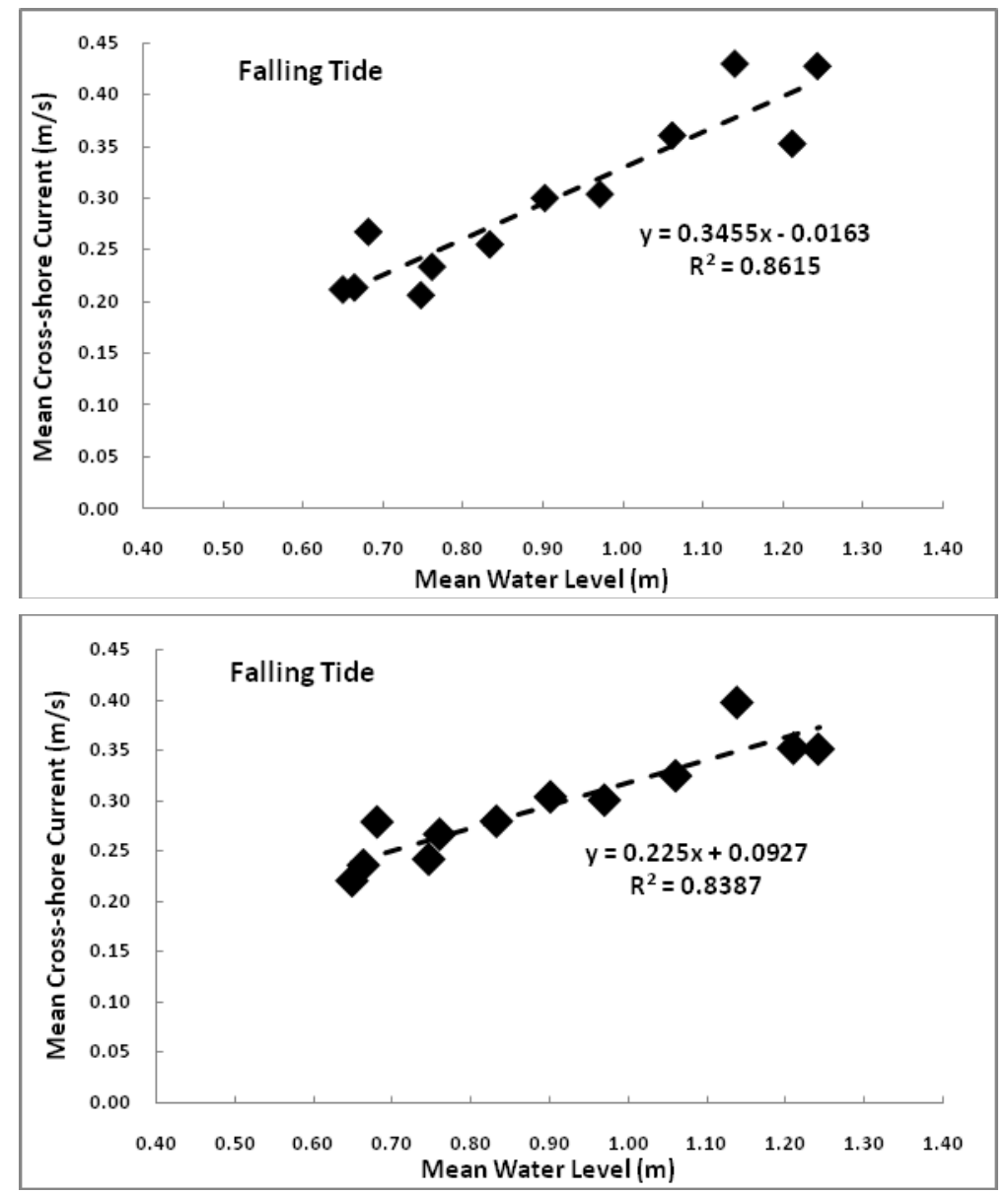

Figure 7: Mean cross-shore current speeds measured at $\mathrm{z}=0.15 \mathrm{~m}$ and the meawater levels recorded in the rip neck during falling water levels (Feb. 19 ${ }^{\text {th }}$ (upper panel) and Feb. 21 $1^{\text {st }}, 2004$ (lower panel). 

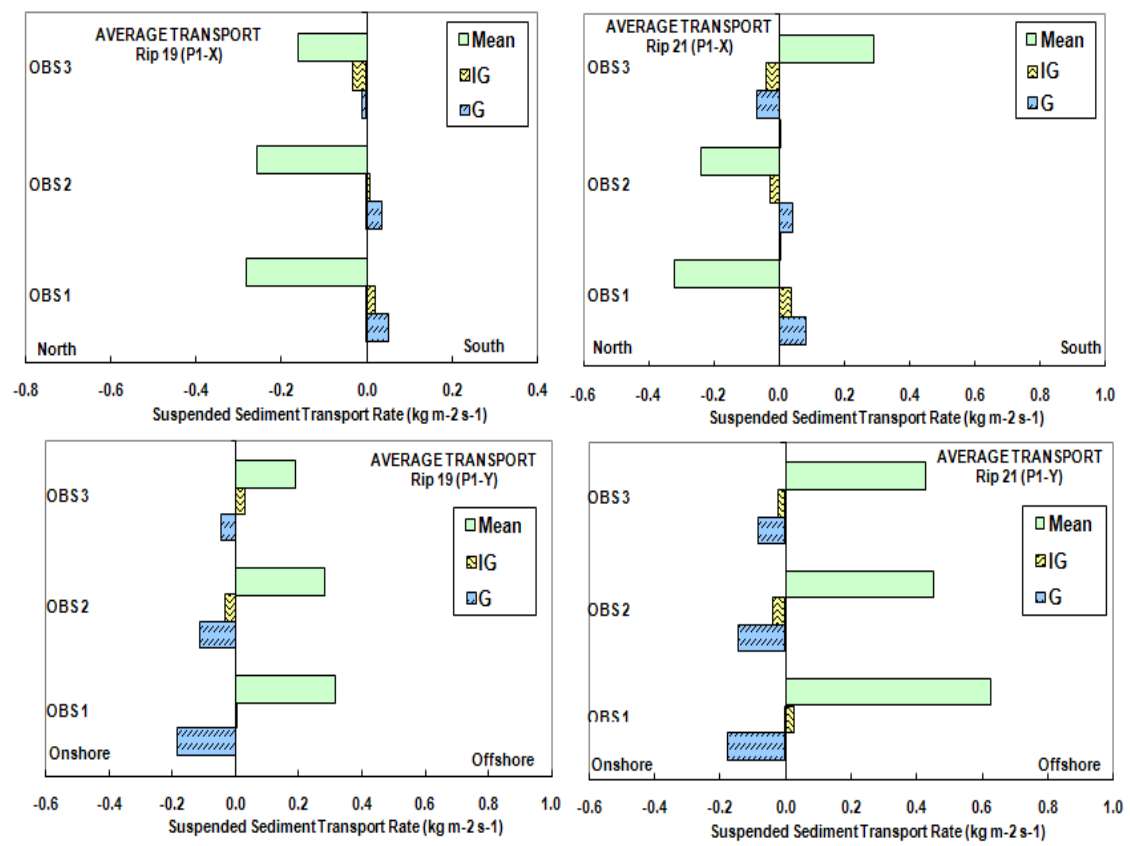

Figure 8: Average suspended sediment transport rates by the mean current (Mean), infragravity (IG) and gravity (G) waves recorded at three elevations in the rip neck $(\mathrm{P} 1)$ on Feb. $19^{\text {th }}$ (left hand panels)and $21^{\text {st }}$ (right hand panels). Rates are disaggregated into alongshore (upper panels) and cross-shore (lower panels) components averaged over the half-tidal cycle.

A linear function explained $>80 \%$ of the velocity variance on both days. It would appear that the reduction in boundary friction per unit volume of flow associated with the deeper water more than compensates for any decrease in breaking or the lack of topographic forcing at the higher water levels. The rip current speed responded more rapidly to tidal change on the $19^{\text {th }}$ than on the $21^{\text {st }}$, probably reflecting the larger wave energies on the $21^{\text {st }}$.

\subsection{Suspended sediment flux in the rip neck}

SST in the rip neck was driven by a combination of: (a) time-averaged, mean currents (the rip current essentially), (b) incident gravity waves and, to a lesser extent, by (c) infragravity waves. The balance between these components controlled both the magnitude and direction of the net flux. Figure 8 illustrates the average cross-shore and alongshore SST rates for all bursts recorded over the half-tidal cycle at each of the three elevations in the rip neck (P1) on Feb. $19^{\text {th }}$ and $21^{\text {st }}$. As expected, the average net flux was seaward and to the north, driven dominantly by the mean rip current following the NE-SW axis of the rip channel. However, this pattern was not consistent throughout the tidal cycle. At high tide on both days, the net SST was indeed dominated by the mean current and 

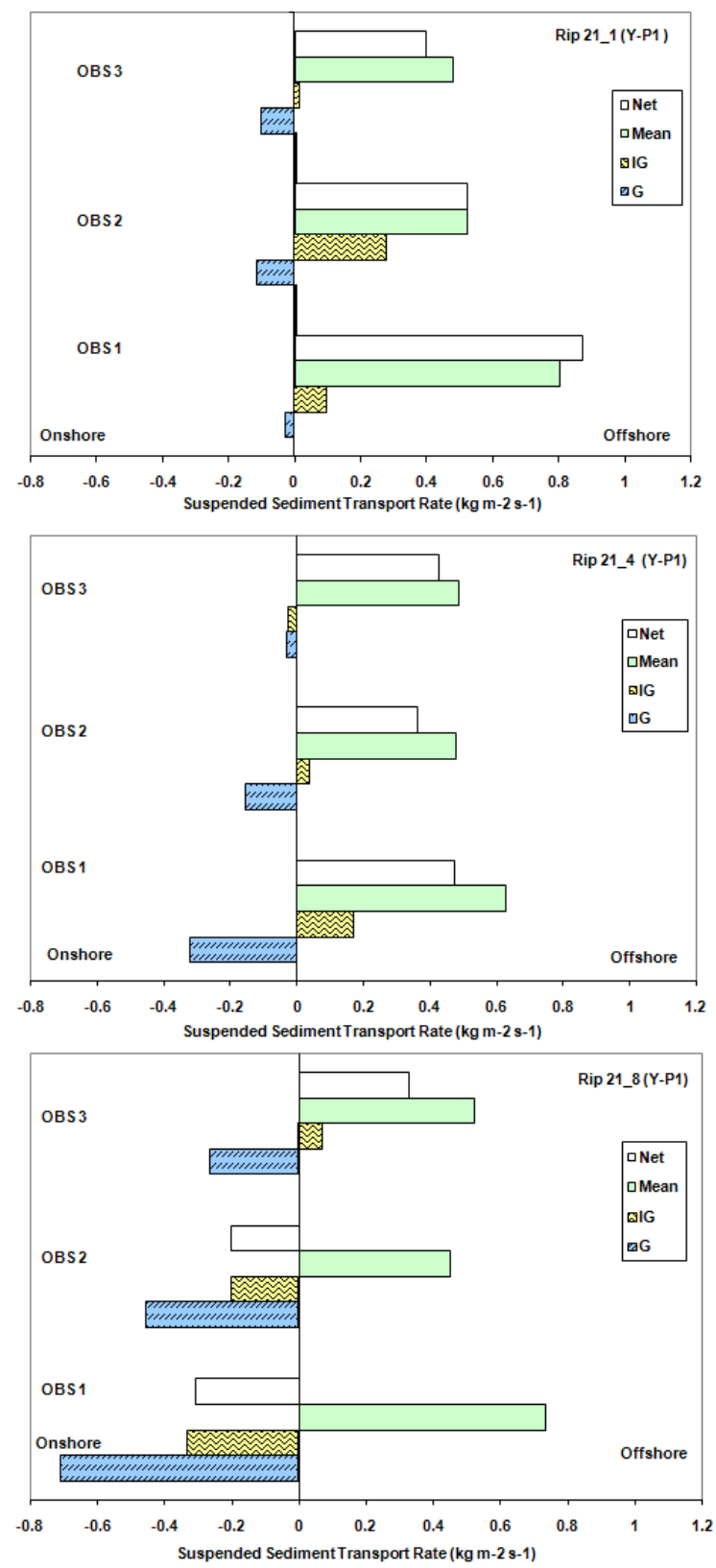

Figure 9: Cross-shore SST rates in the rip neck (P1) at high tide (Rip 21_1), mid-tide (Rip 21_4 and Rip 21_8). The mean current (Mean), infragravity (IG) and gravity $(\mathrm{G})$ wave transports are shown as well as the 17-minute total net (Net) flux. 
directed offshore and to the northeast (Fig. 9). The SST rate attributable to the mean current was of the order of $0.5-1.0 \mathrm{~kg} \mathrm{~m}^{-2} \mathrm{~s}^{-1}$, but decreased with increasing elevation above the bed as expected. At this time, the SST rate of the gravity waves was small, $\leq 0.2 \mathrm{~kg} \mathrm{~m}^{-2} \mathrm{~s}^{-1}$, but directionally in opposition to transport by the rip; incident waves refracting and propagating along the axis of the rip channel at high tide were responsible. Although SST by infragravity waves was present throughout the period of record, at high tide it was relatively small and only important to the alongshore component of transport. As the tide fell, the mean current SST rate continued at the same rate $\left(\sim 0.5-1.0 \mathrm{~kg} \mathrm{~m}^{-2} \mathrm{~s}^{-1}\right)$. Thus, even though the mean cross-shore current velocity decreased as water levels fell, this was offset by an increase in suspended sediment concentrations induced by the increased bed shear by waves with the decreasing water depths. The latter also resulted in a significant increase in SST rates by gravity waves themselves, reaching values similar to those of the mean current $\left(\sim 0.5-1.0 \mathrm{~kg} \mathrm{~m}^{-}\right.$ ${ }^{2} \mathrm{~s}^{-1}$ ). SST by infragravity waves also increased significantly at this time (now of the order of $0.2-0.4 \mathrm{~kg} \mathrm{~m}^{-2} \mathrm{~s}^{-1}$ ) and sediment was transported shoreward to complement the gravity wave transport. The net result was a landward flux of suspended sediment. As low tide was approached (bursts 8-12; Fig. 4), gravity wave transport increased significantly for a short while, up to $\sim 0.7 \mathrm{~kg} \mathrm{~m}^{-2} \mathrm{~s}^{-1}$ (burst $8,1607 \mathrm{~h})$ especially close to the bed $(\mathrm{z}=0.05 \mathrm{~m})$ but decreased rapidly with elevation to $\sim 0.3 \mathrm{~kg} \mathrm{~m}^{-2} \mathrm{~s}^{-1}$ at $\mathrm{z}=0.39 \mathrm{~m}$. This transport reversal meant that at these times sediment was actually moving into the rip cell through the rip neck rather than the reverse. However, although the gravity and infragravity waves maintained an onshore transport until low water, the associated magnitudes dropped and the mean rip current transport, which had remained between 0.5 and $0.8 \mathrm{~kg} \mathrm{~m}^{-2} \mathrm{~s}^{-1}$, assumed its dominance once more.

\section{Conclusions}

The currents and SST rates in a rip neck on a micro-tidal intermediate barred beach during a spring tidal cycle and a period low energy swell and wind wave conditions did not completely support previous studies:

- Rip current speeds decreased rather than increased as tidal levels fell in the rip channel. The rip current was a maximum at high tide and thus the net SST rate was also greatest at this time. The reduction in bed friction per unit volume of water with higher water levels would appear to more than compensate for the bathymetric forcing usually associated with falling water levels in the rip neck.

- During the tidal cycle, the net suspended sediment flux was not directed uniformly offshore; only at high tide when the rip current reached a maximum was sediment transported offshore at all elevations. At mid-tide, swell propagating through the rip channel forced a transport reversal and an onshore net transport of suspended sediment at least near the bed.

- The net flux of suspended sediment did not increase with the falling tidal levels as expected. Although at mid- and low-tide overall transport rates increased significantly, some of this transport was directed onshore by both gravity and infragravity waves in opposition to the mean current, which still transported sediment offshore. 


\section{Acknowledgements}

Funding is acknowledged from NSERC Canada (BG) and an FRGP grant from UNSW (RWB). Mark Daly and Felicity Weir provided valuable field assistance; we are indebted to Dave Mitchell (University of Sydney) for his technical, field and culinary skills. Tom Meulendyk and Heena Dhawan (UTSC) assisted with data analysis, supported by funding from the Government of Canada.

\section{References}

[1] Komar, P.D. Beach Processes and Sedimentation. 2nd Edition, Prentice Hall, New Jersey, p.338, 1998.

[2] Aagaard, T., Greenwood, B., Nielsen, J. Mean currents and sediment transport in a rip channel. Marine Geol., 140: 25-45, 1997.

[3] Brander, R.W. Field observations on the morphodynamic evolution of lowenergy rip systems. Marine Geol., 157: 199-217, 1999.

[4] Brander, R.W. Morphodynamics of a large-scale rip current system at Muriwai Beach, New Zealand. Marine Geol., 165: 27-39, 2000.

[5] MacMahan, J.H., Thornton, E.B., Stanton, T.P., Reniers, A.J.H.M. RIPEX: observations of a rip current system. Marine Geol., 218: 113-134, 2005.

[6] MacMahan, J.H., Thornton, E.B., Reniers, A.J.H.M. Rip Current Review. Coastal Eng., 53: 191-208, 2006.

[7] Wright, L.D., Short, A.D. Morphodynamic variability of surf zones and beaches: a synthesis. Marine Geol., 56: 93-118, 1984.

[8] Greenwood, B, Davidson-Arnott, R.G.D Textural variation in the subenvironments of the shallow-water wave zone, Kouchibouguac Bay, New Brunswick. Canadian J. Earth Sciences, 9: 679-688, 1972.

[9] Austin, M.J., Masselink, G. The effect of bedform dynamics on computing suspended sediment fluxes using optical backscatter sensors and current meters. Coastal Eng. 55: 251-260, 2008.

[10] Jaffe, B.E., Sternberg, R.W., Sallenger, A.H. The role of suspended sediment in shore-normal beach profile changes. Proceedings of the $21^{\text {st }}$ Coastal Engineering Conference, American Society Civil Engineers, p. 1725-1743, 1984.

[11] Osborne, P.D., Greenwood, B. Frequency dependent cross-shore suspended sediment transport 1: a non-barred shoreface, Queensland Beach, Nova Scotia, Canada. Marine Geol., 106: 1-24, 1992.

[12] Huntley, D.A., Hanes, D.M. Direct measurement of suspended sediment transport. Proceedings of Coastal Sediments '87, American Society Civil Engineers, New York, p. 723-737, 1987.

[13] Davidson, M.A., Russell, P.E., Huntley, D.A., Hardisty, J. Tidal asymmetry on a macro-tidal intermediate beach. Marine Geol., 110: 333-353, 1993.

[14] Castello, B., Bonneton, P. Nearshore waves and currents over crescentic bars. Journal Coastal Res., SI39: 687-691, 2004.

[15] Castello, B., Bonneton, P., Sénéchal, N., Dupuis, H., Butel, R., Michel, D. Dynamics of wave-induced currents over a multiple barred sandy beach on the Aquitaine coast. Continental Shelf Res., 26: 113-131, 2006. 